UDC 621.941-229.3:621.822.172

DOI: $10.25140 / 2411-5363-2020-3(21)-203-208$

\author{
Marek Vagaš, Jaroslav Šeminský
}

\title{
SELECTED ASPECTS AND SPECIFICS OF THE ROBOTIC ARM PROGRAMMING AT AUTOMATED WORKPLACES
}

Urgency of the research. It is important to point out at innovative elements in the field of robotic arm programming. At the same time, we want to provide guidance, how to work with these elements further and implement these principles into the automated workplaces control.

Target setting. Purpose of article is to give some form of instruction, how to work with innovative elements for robotic arm programming.

Actual scientific researches and issues analysis. Currently, there are already many innovative and user-friendly programming units on the (automation) market today. Therefore, it is necessary to make the professional public aware of the new possibilities of programming robotic arms.

Uninvestigated parts of general matters defining. The manufacturer's user manual is the most frequently used in this area, but it does not sufficiently describe some aspects of robotic arm programming. Therefore, we consider it is necessary to address at this issue.

The research objective. The aim of article is to provide some kind of instruction, how to work with special equipment, like is programming unit (called also pendant).

The statement of basic materials. For realization of advanced programming functions is good to have a suitable material how to solve path sequence and automation process at the workplace.

Conclusions. Published article presents selected programming aspects for robotic arm with emphasis to specialities of robotic arm manufacturers. Presented article provides a closer view to some detailed solution regarding robotic arm programming that are not often and sufficient described at providers manual.

Keywords: automation; robotic arm; robotic programming.

Fig.: 8. References: 15.

Introduction. The emphasis is put on implementation of advanced programming algorithms together with a simplifying of the robotic arm programming, and as a whole, is constantly growing. Actual pressures comes from the requirements of (especially) automotive industry as well as from the end customers in the position of users. In addition, the programming environment itself is increasingly developed to become more "user friendly". If manufacturers did not take these aspects and requirements into account, it would easily be the case that their products would cease to be produced, profits would fall and the company would lose its competitiveness. The policies of the companies that offer this software are therefore different. Some of them are more user-friendly, whether in the form of available manuals, a better in the form of the off-line environment, low software prices, broad school support and so on [1]. Other providers of these software focus more on the larger "players" in the market and to the implementation of their products in larger companies, such as automakers or large plants. Teaching materials are usually not commonly available, training is expensive, and so on. From the view of robotic arm control, program must be conceived in a way that its structure represents a flexible sequence of moving steps from robotic arm. Focus is led on achieving the desired trajectory from the end effector to the programmed points with required speed and accuracy [2]. At the same time, each robotic arm manufacturer develops and improves their own programming language for programming that is not compatible with each other. However, there is one exception, which is the Siemens software package, "TECNOMATIX (PLM software)". Through this program, it is possible not only programming of complex robotic arm from many others manufacturers, but also the entire complex workplaces, starting by entering of the input parameters to the final assembly time or ergonomic requirements, see Fig. 1.

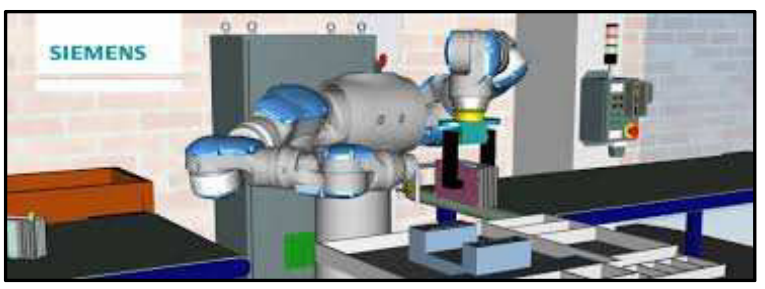

Fig. 1. Siemens TECNOMATIX - PLM software [3]

( Марек Вагаш, Ярослав Семінський, 2020 
Gradually, new industrial languages have been developed for robotic arms that are fast, reliable and relatively simple. An overview of the individual programming languages can be seen at figure 2.

\begin{tabular}{|c|c|}
\hline Manufacturer & Programming language \\
\hline ABB & RAPID \\
\hline KUKA & KRL (Kuka Robotic Language) \\
\hline YASKAWA & INFORM \\
\hline FANUC & KAREL \\
\hline COMAU & PDL2 \\
\hline STÄUBLI & VAL3 \\
\hline $\begin{array}{c}\text { UNIVERSAL } \\
\text { ROBOTS }\end{array}$ & URScript \\
\hline
\end{tabular}

Fig. 2. Available program languages of the robotic manufacturers

Online programming of the robotic arm. On-line programming is (in principle) always characterized by the presence of operator (programmer) directly at the robotic arm. It is realized by a programming unit called teach pendant. It is equipped with a large brightness display, which presents progress of the program or its current status bar together with a switch between manual and automatic operation and the selection of multiple display windows [4]. Control of the robotic arm in manual mode is characterized by gradual guidance to the individual programming points, which are gradually written by the operator (programmer) into the memory of robotic arm control system. Nowadays, modern programming unit (pendants) are already built based PC. The built-in colour display allows the operator to directly program I/O (inputs / outputs) and other functions and also the advanced operation of the robotic arm depending to the built-in functions of robotic arm control system. Some programming units (e.g. COMAU Robotics) are able transmit data to the robotic arm control system via wireless technology [5]. An overview of programming units - pendants of selected companies is shown at figure 3.

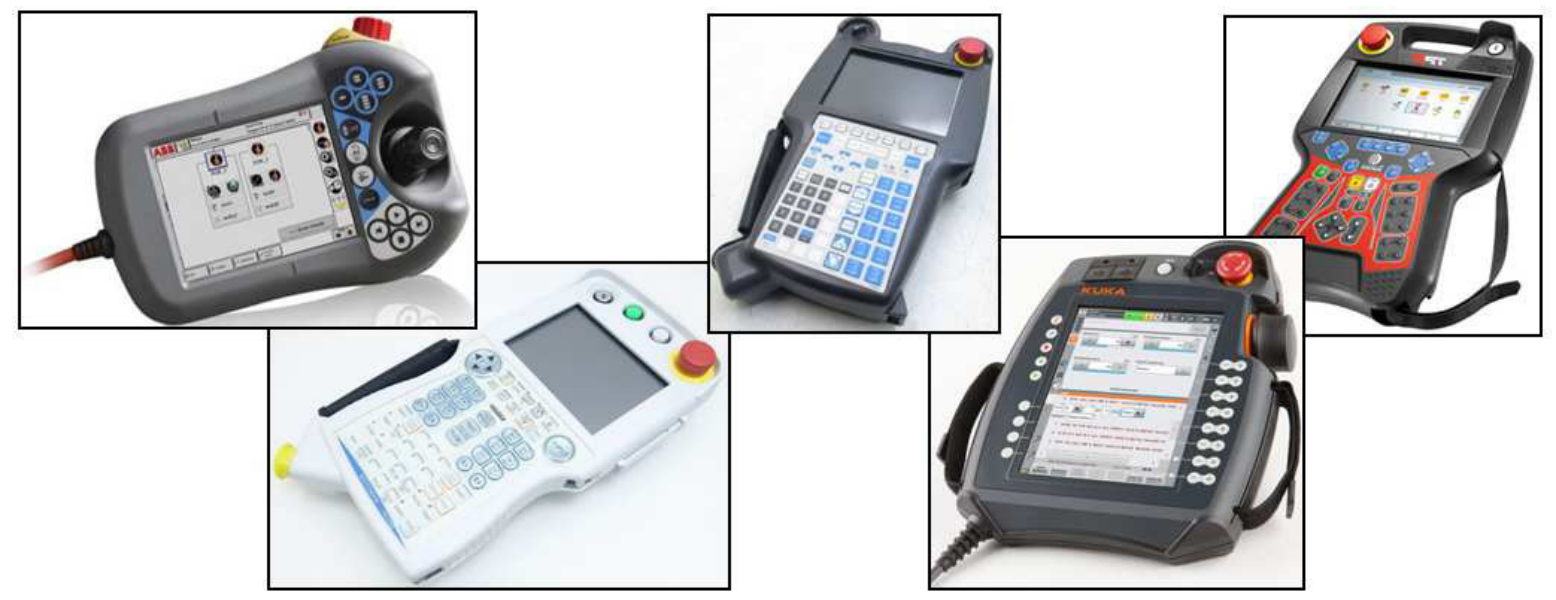

Fig. 3. Selected programmable units - pendants of robotic manufacturers

Off-line programming of the robotic arm. Off-line robotic arm programming begins with a computer model (of the robotic arm, workplace, peripherals) based on increasingly intelligent software packages in an effort to get closer to a real automated workplace. Thus, this type of programming can be characterized as "outside of the automated workplace". The advantage lies mainly in the fact that while automated workplace itself is physically built, their programming activities can be created simultaneously, which leads to great savings in time and costs [6]. 
Errors are permissible and allowed because there is no risk of any real damage, in addition to the real automated workplace, these ways can be fully tested before their complete physical start-up. Off-line programming enables a complex description of the assigned task, experiments with the structure of the automated workplace, elimination of collision situations or verification of the program in 3D representation, see figure 4.

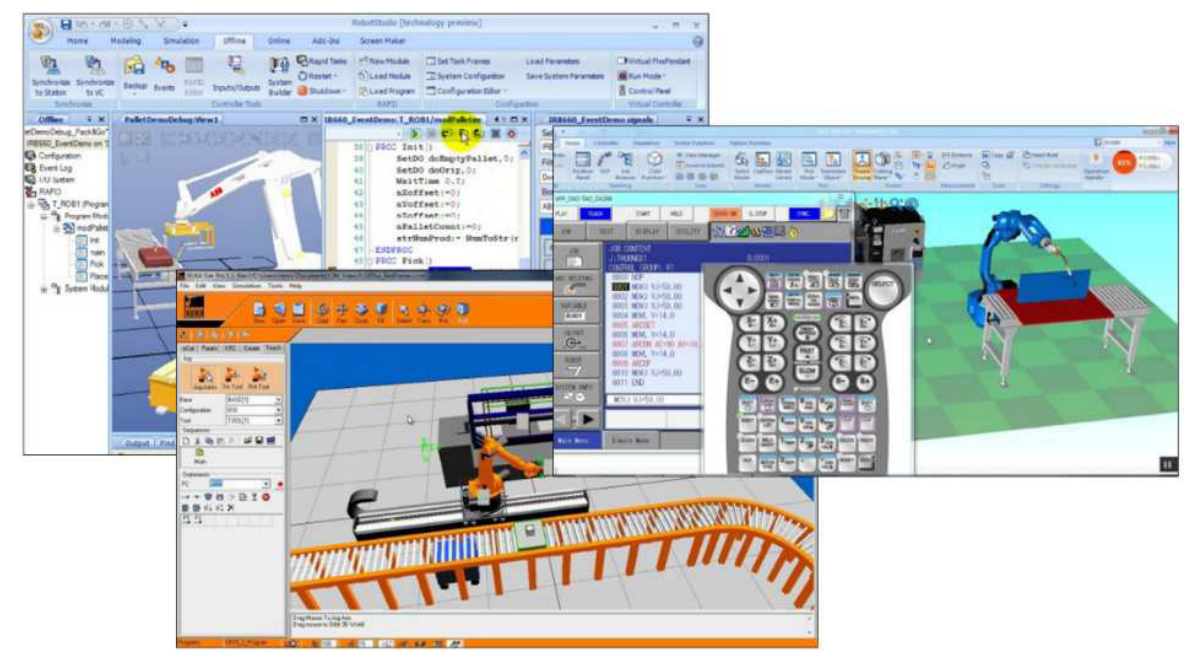

Fig. 4. Overview of some off-line environment from robotic manufacturers

Specifics of the robotic arm programming. Gradual learning - the robotic arm is gradually guided by the operator in this way (programmer) using the buttons directly on the pendant to the individual positions, (in which an action is to be performed, e.g. gripping, or tool operation) and the coordinates of these precisely tuned positions and the orientation of the tool are stored in the memory of the control system [7]. During automatic operation, the robotic arm then uses this data from the memory of the control system. Positions of the individual points and tool orientation at these points are automatically recorded according to the manual setting, in this method. Other functions of the robotic arm are programmed using a PC or directly inside the editor of programming unit [8]. Programming units enable monitoring of inputs / outputs and system information, writing programs in the editor, allowing access to production data (average cycle time, number of production cycles, ...), setting of working parameters e.g. for welding directly from the pendant. More modern units have analytical functions to optimize the work of the robotic arm.

Guidance programming - is very popular and is used to program simple and less accurate application movements (painting, spraying, etc.). The programming process begins with the manual guidance of the robotic arm by the operator (programmer) manually. Control system records this movement, i.e. writes to memory at regular periodic intervals. In particular, data of the position and orientation of tool [9]. When automatic operation is started, the robotic arm plays back the recorded activity. Repetition of the movement path is not entirely accurate, because the robotic arm itself is loaded in the opposite direction when repeating the movement than when guiding along the desired path were [10]. Main reason lays at the deviations that are defined by the clearances in the bearings and the flexibility of the structure have opposite orientations. Another disadvantage of this specificity is presence of the operator, which can cause big problems in small spaces, but the creation of the program is relatively fast.

$\underline{\text { SmartPAD }-i t ~ i s ~ a ~ s p e c i f i c ~ p r o g r a m m i n g ~ u n i t, ~ w h i c h ~ i s ~ c h a r a c t e r i z e d ~ b y ~ a ~ l a r g e ~ a n d ~ c l e a r ~}$ display with function keys for speed settings, coordinate system settings and central stop [11]. The specialty is a button for software disconnection of the programming unit as well as a 6D mouse for manual control of the robotic arm, see figure 5 . 


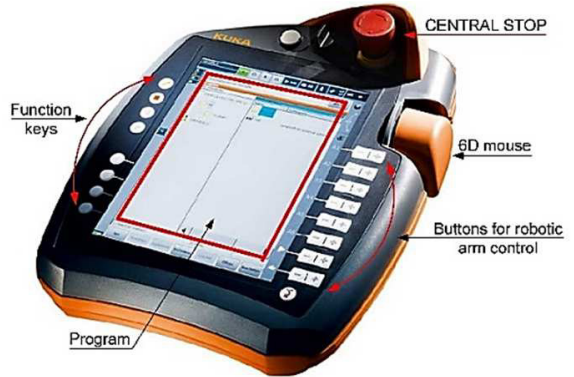

Fig. 5. Overview of some off-line environment from robotic manufacturers

The specificity of programming lies in the control of individual axes of the robotic arm, which are intuitively controlled by a 6D mouse. Depending on the dominant mode, the control can be used to move one or more axes simultaneously [12]. Robotic arm can move e.g. just by pulling or squeezing this control. Movements at axes $\mathrm{X}, \mathrm{Y}$ a $\mathrm{Z}$ is possible to realize according to the figure 6 .

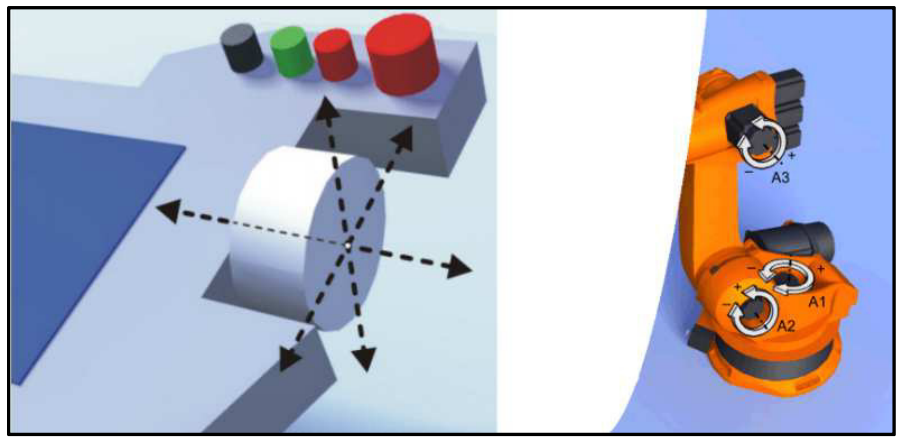

Fig. 6. Movements when pressed or pulling $6 D$ mouse

The robotic arm can also be moved by turning or by tilting the control via $6 \mathrm{~d}$ mouse. Following rotary movements in the axes A4, A5 and A6 can be realized according to figure 7 .

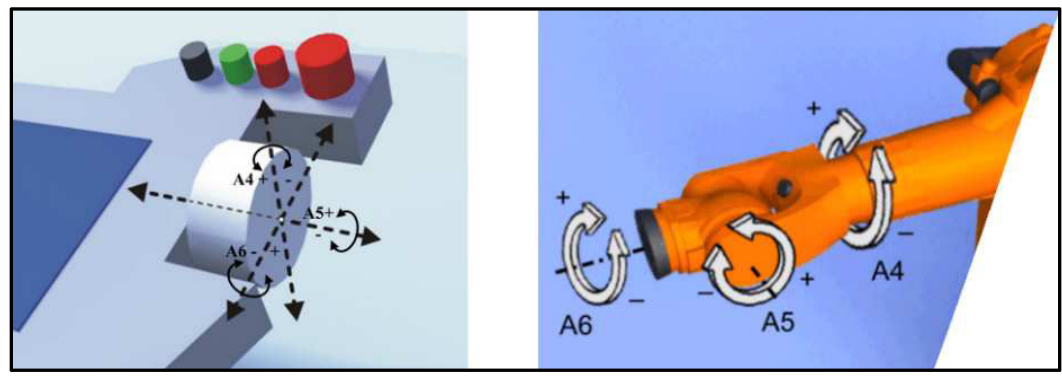

Fig. 7. Movements during rotation or tilting the $6 D$ mouse

In the following configuration, it is possible to move all 6 axes of the robotic arm. When the rectangular coordinate system is set, pushing and pulling the Space-Mouse along their X, Y or $\mathrm{Z}$ axis causes a corresponding movement of the robotic arm along the $\mathrm{X}, \mathrm{Y}$ or $\mathrm{Z}$ axis of the set reference coordinate system [13]. Rotation of the element about the X, Y or Z axes also causes the corresponding rotation of the tool about the $\mathrm{X}, \mathrm{Y}$ or $\mathrm{Z}$ axis, figure 8 .

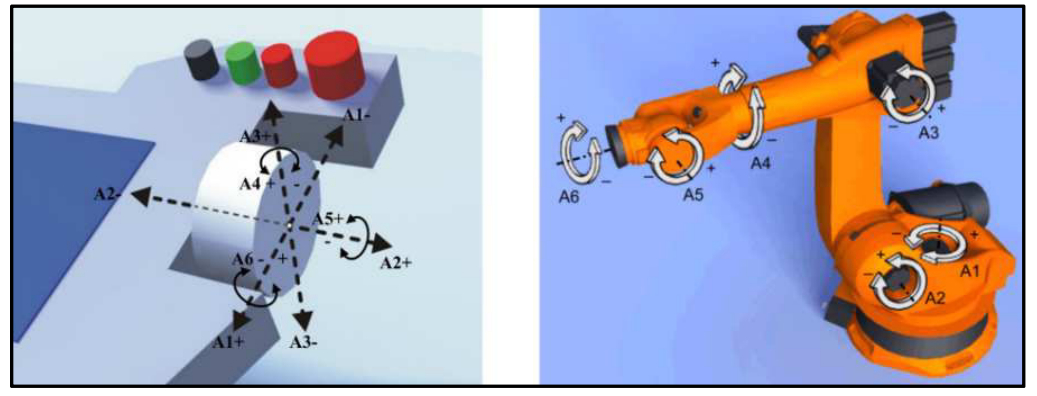

Fig. 8. Unlimited functionality of the $6 D$ mouse element 
TECHNICAL SCIENCES AND TECHNOLOGIES

Conclusions. Current trends in the field of control and programming of industrial robotic arms in automated operations are focused on remote mobile control via the cloud [14]. The industrial robotic arm is controlled by a PLC stored in the cloud space. This trend is proving to be one of the possibilities for the implementation of the upcoming digitization of industrial processes, the ultimate goal of which is to achieve "smart factories“. The way to get to this vision is definitely advanced image processing with "machine vision" technology for maximum flexibility and efficiency within the automated assurance of process continuity and quality [15]. A common and fundamental principle is the advanced cooperation of sensor systems in order to share their status and collect data for manufacturers. This process makes it possible to exchange information independently, to manage and to cooperate with each other between the various levels of management systems.

Acknowledgement. This work has been supported by the Slovak Grant VEGA 1/0330/19 - Research and design of algorithms and systems for the fusion of heterogeneous data in multisensor architectures.

\section{References}

1. Consiglio, S., G. Seliger, N. Weinert. (2007). Development of Hybrid Assembly Workplaces. In: CIRP Annals, Volume 56, Issue 1, 2007, Pages 37-40, ISSN 0007-8506.

2. Vagaš, M., Šimšík, D., Onofrejová, D. (2019). Factors for successfully implementation of automated solutions based on industry 4.0. In: ARTEP 2019, Automatizácia a riadenie v teórii a praxi. 13. ročník konferencie odborníkov $\mathrm{z}$ univerzít, vysokých škôl a praxe. Košice: Technická univerzita $\mathbf{v}$ Košiciach, s. 1-8. ISBN 978-80-553-3250-5.

3. J. Krüger, T.K. Lien, A. Verl. (2009). Cooperation of human and machines in assembly lines. In: CIRP Annals, Volume 58, Issue 2, Pages 628-646, ISSN 0007-8506. https://www.plm.automation.siemens.com/ global/en.

4. Senderská K. (2002). Inovačné metódy a techniky a ich uplatnenie v procese projektovania montážnych systémov. In: Transfer inovácií 5/2002. Košice: TU, SjF, č.5/2002, s. 124-126. ISBN 8070999527.

5. Semjon et. al. (2018). Comparison of the delta robot ABB IRB 360 properties after collisions. In: Communications - Scientific Letters of the University of Zilina. Vol. 20, no. 1, p. 42-46. ISSN 1335-4205.

6. Vagaš, M., Semjon, J., Hajduk, M. (2016). Realisation of experimental cooperative workplace for assembly tasks. In: Advances in Robot Design and Intelligent Control. Zurich: Springer, P. 361-369. ISBN 978-3-319-49057-1.

7. Kuka Roboter GmbH. Operating and Programming Instructions for System Integrators, Kuka System software 8.3, 14.1. 2015, Version: KSS 8.3 Si V4. 2015.

8. Björn M.. ISO/TS 15066 - Collaborative Robots - Present status. In.: Conference-European Robotics Forum, 2015, Vienna, Austria. ISBN 978-1-8578-4776-3/02.

9. Vagaš, M. (2015): Increasing of operational safety robotized workplaces by sensor equipment, Global management and economics, No. 1, p.158-162, 2015.

10. Shigang Yue, S.K. Tso, W.L. Xu. (2001): Maximum-dynamic-payload trajectory for flexible robot manipulators with kinematic redundancy, Mechanism and Machine Theory, Volume 36, Issue 6, Pages 785-800, ISSN 0094-114X.

11. Popovič, R., Trebuňa, P., Kliment, M., Pekarčíková, M. (2015): Simulation as a part of business process modeling. In: Acta Simulatio - International scientific journal about simulation. Volume 1, Pages 13-16. ISSN: 13399640.

12. Panagiota T., Matthaiakis A., Makris, S., Chryssolouris, G. (2017).On a human-robot collaboration in an assembly cell. In.: International Journal of Computer Integrated Manufacturing. Vol. 30, No. 6, 580-589. ISSN 0951-192X.

13. Marvel, J., Norcross, R.: Implementing Speed and Separation Monitoring in Collaborative Robot Workcells. In: Robotics and Computer-Integrated Manufacturing, Journal. Vol.44, Pages: 144-155. ISSN 0736-5845. 
14. Nokata, M., Ikuta, K., Ishii, H. Safety-optimizing method of Human-care Robot Design and Control. (2002) In.: Proceedings of the 2002 IEEE, International conference on robotics and automation, USA, ISBN 0-7803-7272-7/02.

15. Makris, S., Tsarouchi, P., Surdilovic, D., Krüger, J. (2014): Intuitive dual arm robot programming for assembly operations, CIRP Annals - Manufacturing Technology, Volume 63, 2014, Issue 1, Pages 13-16. ISSN: 0007-8506.

\section{УДК 621.941-229.3:621.822.172}

\section{Марек Вагаш, Ярослав Семінський}

\section{ДЕЯКІ АСПЕКТИ ТА СПЕЦИФІКИ ПРОГРАМУВАННЯ РУК РОБОТІВ НА АВТОМАТИЗОВАНИХ РОБОЧИХ МІСЦЯХ}

Актуальність теми дослідження. Важливо відзначити інновачійні елементи в галузі програмування роботизованої руки. Водночас ми хочемо надати інструкцію, як працювати з ичими елементами далі і впровадити цฺі принциипи в систему керування автоматизованими робочими місиями.

Постановка проблеми. Надання деякої форми інструкиї̈, як праџювати з інноваційними елементами для програмування роботизованої руки.

Аналіз останніх досліджень і публікацій. Нині на ринку автоматизації вже є багато інноваиійних $і$ зручних для користування пристроїв програмування. Отже, необхідно ознайомити професійну громадськість із новими можливостями програмування роботизованої руки.

Виділення недосліджених раніме частин загальної проблеми. Керівництво користувача від виробника є найчастіше використовуваним у цій сфері, але воно недостатньо описує деякі аспекти програмування роботизованої руки. Тому ми вважаємо за необхідне зайнятися изи питанням.

Постановка завдання. Надання інструкиію, як праџювати зі спеџіальним обладнанням, наприклад, із блоком програмування (підвісним пристроєм).

Виклад основного матеріалу. Для реалізації розширених функцій програмування добре мати відповідний матеріал, як вирішувати послідовність шляхів і прочес автоматизації на робочому місиі.

Висновки відповідно до статті. Опублікована стаття надає вибрані аспекти програмування роботизованої руки $з$ акиентом на спеиіальності виробників роботизованих рук. Представлена стаття надає більи детальний огляд деяких детальних рімень щзодо програмування роботизованих рук, які нечасто і недостатньо описані в керівництві виробників.

Ключові слова: автоматизачія; роботизована рука; роботизоване програмування

Рис.: 8. Бібл.: 15

Vagas Marek - Doctor of Technical Sciences, associate professor, Technical University of Kosice, Faculty of Mechanical Engineering, Department of automation and human machine interactions (9 Letna Str., 04100 Kosice, Slovakia).

E-mail: marek.vagas@tuke.sk

Scopus Author ID: 55014596100

Jaroslav Šeminský - Doctor of Technical Sciences, associate professor, Technical University of Kosice, Faculty of Mechanical Engineering, Department of automation and human machine interactions (9 Letna Str., 04100 Kosice, Slovakia).

E-mail: jaroslav.seminsky@tuke.sk

Scopus Author ID: 35933017800

Vagaš, M., Šeminský, Ja. (2020). Selected aspects and specifics of the robotic arm programming at automated workplaces. Technical sciences and technologies, 3(21), pp. 203-208. 